\section{Baden-Powell on teeth: a centenary perspective of a pioneer of preventive dental health}

\author{
J. Pearn ${ }^{1}$
}

IN BRIEF

Lord Baden-Powell showed that:

- Dental hygiene was the most fundamenta indicator of the 'civilised life'.

- Care of the teeth is practical even in the most difficult of physical circumstances.

- Simple messages of preventive health and dental hygiene can reach the widest audience if such are made relevant to the target population 'at risk'

In the era when dental care, particularly preventive dental health, did not enjoy a high public profile, Lieut-General (later Lord) Robert Baden-Powell (1857-1941) was an influential advocate for the care of the teeth. He was a pioneer in a targeted outreach to youth, specifically boys and young men, emphasising the importance of dental health as an essential part of total body health and fitness. In his book, Scouting for boys, first published on 1 May 1908, he described personal accounts of the consequences of the neglect of oral hygiene and presented advice on how to make an effective 'camp toothbrush' in order that dental hygiene would not be compromised even under the exigencies of conditions away from home. Baden-Powell wrote explicitly that daily dental hygiene was the single most important 'one civilised thing [teenage youths] could do', irrespective of one's physical circumstances. Scouting for boys was for more than five decades the world's best seller in English, after the Bible. It has run to, and now surpasses, 60 million copies in 30 languages and has been published in 35 editions. It is believed that Baden-Powell's frank and direct exhortations to preserve the teeth, with simple and direct advice on food and what today would be called oral hygiene, have been read by 350 million people throughout the world. His advocacy reached out to boys and young men as it does today to youths of both sexes in that 'window of opportunity' when life-long habits of healthcare are being inculcated and when important components of secondary dentition are forming. This paper is a centenary perspective of Baden-Powell's pioneering advocacy of modern preventive dental health.

Dental health, particularly preventive dental care, was a neglected theme in the early twentieth century. One powerful advocate for improved dental care, as an important component of total body health, was Lieutenant-General (later Lord) Robert Baden-Powell (1857-1941), ${ }^{1}$ founder of the Boy Scout movement.

His book, Scouting for boys, ${ }^{2}$ published in 1908, was one of the best-selling works in English in the twentieth century. $^{3}$ In the five decades after its publication, its sales were exceeded only by those of the Bible..$^{3,4}$ In the centenary year of scouting, Scouting for boys has

\footnotetext{
'Professor, Faculty of Health Sciences, University of Queensland and Department of Paediatrics \& Child Health, Royal Children's Hospital, Brisbane Old 4029, Australia

Correspondence to: Professor John Pearn Email:.j.pearn@uq.edu.au
}

\section{Refereed Paper}

Accepted 17 July 2007

DOI: $10.1038 /$ bdj.2007.1187

${ }^{\oplus}$ British Dental Journal 2008; 204: 33-36 run to 35 editions, has been translated into 30 languages and has achieved sales exceeding 60 million copies. ${ }^{4,5}$ Originally an organisation for boys, today scouting is open to all and remains the largest international youth organisation in the world, with some 30 million uniformed members.

Baden-Powell promoted the centrum of optimal personal health as part of his philosophy of the desirable life. He highlighted the importance of preventive medicine in all its aspects, and specifically expounded the importance of dental care in an era when such was unfashionable. Since the inception of Scouting, this health message has touched 350 million people across the globe. ${ }^{3}$ This paper is a perspective analysis of his advocacy for the attainment and maintenance of dental health, in the centenary year of his invention of Scouting.

\section{Scouting for boys}

Baden-Powell was a British cavalry officer whose leadership throughout the
Siege of Mafeking (lifted after 217 days on 17 May 1900) brought him fame, even adulation, during and in the immediate aftermath of the Anglo-Boer War (18991902). Concerned about the plight, both in health and in moral terms as he saw it, of British boys - especially youths from underprivileged social backgrounds - he conceived the idea of founding a collegiate movement which would promote good citizenship and which would provide an identified infrastructure for personal fulfilment.

He was influenced by the success of a growing number of existent youth organisations such as The Boys' Brigade, the Church Lads' Brigade and the Boys' Empire League in the United Kingdom; the Temperance Cold Water Army and the Woodcraft Indians in the United States; the Queen's Corps of Guides in India; and the Boy Guides' Brigade in South Africa.

He was concerned about published statistics which showed falling standards of child and teenage health, including dental health, in the United Kingdom. ${ }^{1,6,7}$ 
These included appallingly high indices of dental ill health ${ }^{7}$ which would be equated with scandalous DMFT indices today. Against this background his instinct was that there was both an opportunity for and a growing societal need for a collegiate uniformed youth organisation 'whose time had come' and in which his concepts of preventive health might be embedded. BadenPowell's personal vision was to see the need for an organisation which was less militaristic than The Boys' Brigade, ${ }^{3}$ less 'religious' than other youth groups ${ }^{6}$ and one which frankly would promote outdoor adventure and good fun. BadenPowell's original concepts were that 'Scouting would be as free of 'red tape' as possible and as little like the management of business as possible'.

He espoused his unique doctrine in Scouting for boys which first appeared 'in a somewhat ramshackle six-part edition in early 1908' ${ }^{3}$ Its compilation was 'composed at speed - patched together ... in an experimental and even pellmell way... at his elbow where he worked stood an old military dispatch box full of scraps; newspaper cuttings, extracts torn from adventure novels and travel writing, other magpie texts and pieces of information'. ${ }^{3}$ Scouting for boys was initially sold in parts every second Wednesday at newsagents and by newsboys for an affordable fourpence a copy. The first complete book was published on 1 May 1908, by Horace Cox, a printer of London and was sold for two shillings (Fig. 1). Its influence was to be immense. An experimental Scout camp embodying 'B-P's' concepts of outdoor adventure, fun and fitness, was held on Brownsea Island, off Poole, in 1907. It was followed by the first uniformed Scout camp which was held at Carr Edge near the hamlet of Fourstones near the village of Humshaugh, several kilometres south of Hadrian's Wall in Northumberland in 1908 (Fig. 2). By 1909, 107,000 boys and young men were in uniform in the Boy Scout movement.

\section{Dental health}

Chapter VI of B-P's Scouting for boys was entitled 'Endurance for Scouts; Or, How to be Strong'. It incorporated three 'Campfire Yarns', entitled:
No. 17. How to Grow Strong - Care of the Body, Nose, Ears, Eyes and Teeth.

No. 18. Health-giving Habits.

No. 19. Preventing Disease. ${ }^{6}$

In the preamble to this chapter, BadenPowell expressed his concern for deteriorating health standards among English youth. He quoted the disturbing figures (not only of concern to him but to the British public), that the recruit standards for height, for entry into the British Army, had had to be reduced from a minimum of 5' 6' in 1845 to 5' 2' in 1895.

He was particularly concerned with the state of dental ill health in British youth in the late nineteenth and early twentieth century. He wrote with concern that:

'Three thousand men were sent home from the South African War on account of bad teeth"

and that:

'Reports on school children, made by the London County Council, showed that out of 700 examined only 20 had sound teeth - 323 had more than five teeth decayed'.

Baden-Powell was acutely aware of the particular plight of the socially disadvantaged, specifically in the context of dental decay. He wrote that contrary to the appallingly low standards of dental health among the poorer classes, a recent study of a thousand London 'Thirteen year old school boys, sons of rich or wellto-do persons... the teeth were well cared for.' ${ }^{7}$ His health and dietary messages in Scouting for boys were constantly couched in terms of practical advice that could be followed by all, without expense.

His advocacy in the promotion of positive health was one of preventive health practices. He wrote that:

'these [problems of health, including decayed teeth] and many similar reports show that much PREVENTABLE deterioration is being allowed to creep in among the rising generation'. ${ }^{8}$

His emphasis on preventive physical and dental health was very much that of the strongest advocacy for personal responsibility for one's health. In this context he wrote:

'For these reasons the following Chapter [Chapter VI of Scouting for boys] suggests the instruction of boys in being PERSONALLY RESPONSIBLE [his capitals] for their own Strength, Health and Sanitary Surroundings'. ${ }^{8}$

\section{Scouting}

for Boys.

A HANDBOOK FOR INSTRUCTION
GOOD CITIZENSHIP.

Licut,-Oeaeral R. S. S. BADEN-POWELL, C.8, r.e.s.

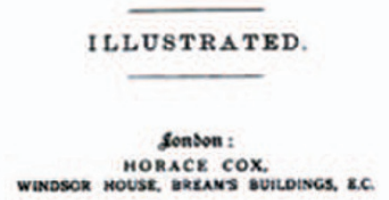

Fig. 1 The frontispiece of Robert BadenPowell's Scouting for boys, first published in book form on 1 May 1908. It was the English best-seller, next after the Bible, for the ensuing $\mathbf{5 0}$ years. Its health messages, including advice on dental hygiene, were contained in a continuing print run, now exceeding 60 million copies, throughout its ensuing 35 editions. It has been translated into $\mathbf{3 0}$ languages and has influenced $\mathbf{3 5 0}$ million people worldwide

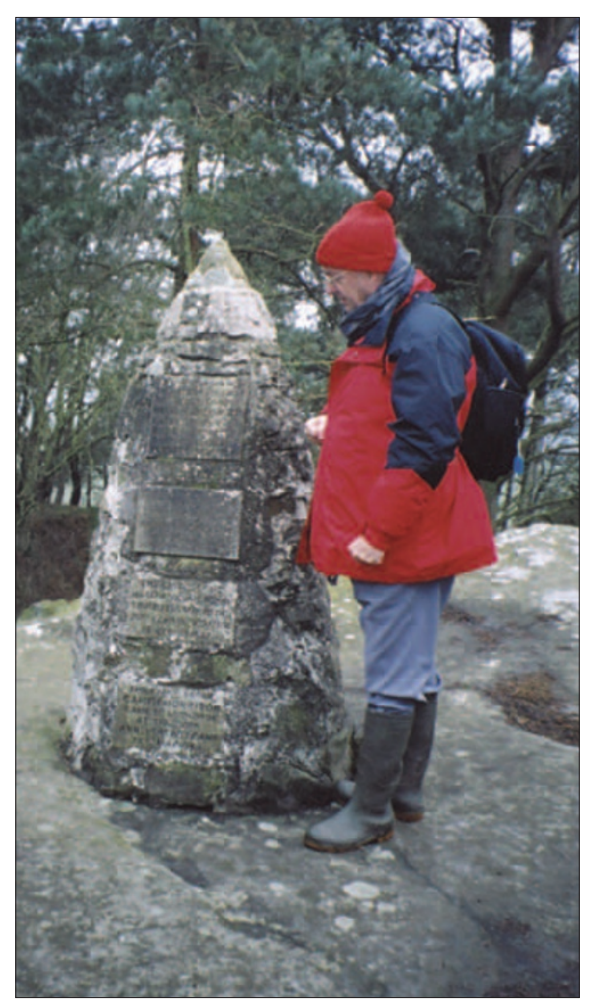

Fig. 2 The site of the first uniformed Scout Camp, held in 1908 at Carr Edge, near the hamlet of Fourstones near the village of Humshaugh, four kilometres south of Hadrian's Wall, Northumberland, UK. A photograph of the author at the site on the occasion of the Centenary of Scouting, 2007 


\section{The teeth}

In 1908, 'B-P' wrote a specific section in Scouting for boys entitled 'Teeth. ${ }^{9}$ His style was to recount three short anecdotes; two from his own wartime experience as a Major General in the British Army in Africa.* These examples of the importance of care of the teeth took the form of allegories to highlight his preventive dental health message. The first of these read:

'A WOULD-BE recruit came up to the recruiting officer to be enlisted in the Boer War. He was found to be a sufficiently strong and well-made man but when they came to examine his teeth they found that these were in bad condition, and he was told that he could not be accepted as a soldier. To this he replied: 'But, Sir, that seems hard lines. Surely we don't have to eat the enemy when we've killed them, do we?'

He published a diagram of how to make a 'camp tooth-brush' from a sixinch twig, frayed at one end (Fig. 3). His practical suggestion and details on how to make this camp toothbrush ${ }^{10}$ was an excellent exemplar of his skill in popularising artefacts which had about them the whiff of adventure yet the self-evident logic of utility. It was said that:

'He [Baden-Powell] was the master of knots and guises, dodges and decoys'. ${ }^{3}$

His toothbrush was iconic of his whole pastoral adventurism. With the illustration of his bush toothbrush, he recounted a parable which featured cowboys 'out west' in the United States, who:

'live a hard life, doing hard and dangerous work, far away from towns and civilisation - where nobody sees them. But there is one civilised thing that they do - they clean their teeth every day, morning and evening: ${ }^{10}$

This philosophy and approach to dental hygiene was to have a resonance 95 years later, in a world of whose evolving technological developments Baden-Powell could have had no concept, when in 2003:

'The toothbrush was selected as the number one invention Americans could not live without, beating out the automobile, computer, cell phone, and microwave oven'. ${ }^{11}$

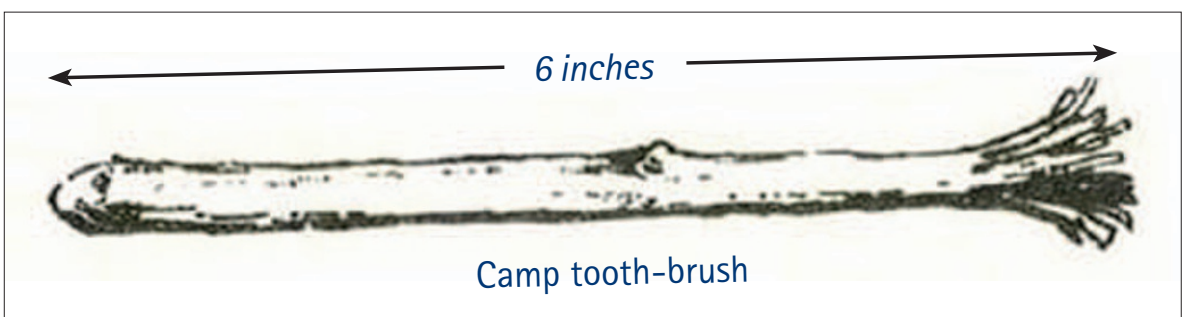

Fig. 3 Baden-Powell's illustration of a 'camp tooth-brush', published in Scouting for boys, in Camp Fire Yarn No. 17, in May 1908. With acknowledgements to the original printer, Horace Cox, and the publisher, C. Arthur Pearson and The Scout Association

Baden-Powell's 'camp tooth-brush' was in fact a slightly modified 'chew stick', known from anthropological studies to have been in existence since 3000 BC. ${ }^{12}$ Thebristletoothbrush, putatively invented in China in 1498, had been in mass production in England since 1780. ${ }^{13,14}$ Thus the appalling indices of dental ill health which concerned Baden-Powell were in part not due to the lack of toothbrushes, but to social class disadvantage with its consequent lack of the perceived need for and the physical reality of their use.

Not all Baden-Powell's teaching about health matters have stood the test of time or the advance of knowledge. His teaching that masturbation was an important cause of insanity is now regarded as ludicrous. His dietary advice, although essentially sensible with respect to moderation and balance, was aimed particularly at economy - again directed for pragmatic reasons particularly to underprivileged youth. He recommended:

'The cheapest and best foods [which] are dried peas, flour, oatmeal, potatoes, hominy and cheese... bananas are especially good food, they are cheap, have no seeds or pips to irritate your inside...'

Hominy is coarsely ground maize boiled with water or milk. Such glutinous and teeth-adherent foods as hominy, flour and oatmeal are splendid nutritionally (as he implied), but it was soon appreciated that special attention to dental hygiene was needed in a highly farinaceous diet in which refined starches were in high proportion.

\section{Aftermath}

It is impossible to measure how effective Baden Powell's advocacy for dental health really was. Seven years after Scouting for boys was published and millions of copies sold, at the outbreak of the First World War measures of dental health were still appalling. Many of the servicemen who volunteered to serve in the First World War had themselves been Boy Scouts. When the First AIF reached Egypt (1914), Lieutenant Colonel Frank Marshall (later Staff Officer of the Australian Dental Service) reported:

'The dentists working with Units were absolutely unable to do more than touch the fringe of what was demanded of them... ${ }^{15}$

In the ANZAC contingent of the Gallipoli Campaign, dental disease and dental deficiency caused a very significant loss of fighting manpower. One in every 13 of the medical evacuations among ANZACS from Gallipoli was for dental illness. The figures for the British forces were probably higher. Colonel A. G. Butler, the Brisbane paediatrician and later Medical Historian of the First World War, was to write that:

'Pyorrhoea [on Gallipoli] was very prevalent; caries took on acute form, even more than in June and July [1915]; on the physiological side the fact was brought home that civilized man is largely dependent on artificial dentition. The hopeless situation in respect of treatment... during that [Gallipoli] period ... brought about the stoppage of dental evacuation, and [finally] led to local attempts at treatment. ${ }^{.16}$

Interestingly, the primary ethos of Baden-Powell's promotion of personal health and fitness in all its forms was not primarily for self-interest. It was to enable one to 'Be Prepared' to help others both in daily civilian life and in emergencies. He stressed that a healthy body was a prerequisite for this Good Samaritan ethic. In this, he differed from the 
raison d'être of maintaining personal physical health and fitness which is the norm in the twenty-first century, where our current motivation is that of selfinterest. Today, the primary desideratum for optimal general and dental health is the fulfilment that follows good health for one's own sake.

Like so many of Scouting's themes, this change in emphasis has reflected changing paradigms in society more generally. In the military context, if manpower is lost by neglecting avoidable preventive health practices, others also suffer and the primary aim of military deployment may be compromised. Such was true in Baden-Powell's time and remains a basic truth today. In the civilian world also, although today the health ethos is primarily one of the preservation of health and the prevention of disease for reasons of self-interest, if dental caries develops, family resources are diverted and others may have their lives disadvantaged by the cost of compensatory dental treatment. For these personal, family and societal reasons, B-P's pioneering and passionate advocacy for optimal dental health retains its relevance today.

1. Jeal T. Baden-Powell. Founder of the boy scouts. Yale: Yale University Press, 1989.

2. Baden-Powell R S S. Scouting for boys. A handbook for instruction in good citizenship. London: Horace Cox, 1908.

3. Boehmer E (ed). Introduction. In Baden-Powell R SS. Scouting for boys. pp xi. Oxford: Oxford University Press, 2004.

4. Jeal T. Baden-Powell: founder of the boy scouts. pp 396. New Haven: Yale University Press, 2001.

5. Springhall J. Youth, empire and society: British youth movements, 1883-1940. pp 68. London: Croom Helm, 1977

6. Baden-Powell R S S. Op. Cit pp 183.

7. Baden-Powell R S S. Op. Cit. pp 184.

8. Baden-Powell R S S. Op. Cit. pp 185.

9. Baden-Powell R S S. Op. Cit. pp 190-192.

10. Baden-Powell R S S. Op. Cit. pp 191.

11. Toothbrush beats out car and computer as the invention Americans can't live without, according to Lemelson-MIT survey. MIT online news office, 21 January 2003. http://web.mit.edu/newsoffice/2003/lemelson.html

12. US Library of Congress. Who invented the toothbrush and when was it invented? http://www.loc. $\mathrm{gov} / \mathrm{rr} / \mathrm{scitech} / \mathrm{mysteries/tooth.html}$

13. McGrath K A, Travers B (eds). World of invention. pp 805-806, 1043. Detroit: Gale, 1999.

14. Panati C. Extraordinary origins of everyday things. pp 208-210. New York: Harper and Row, 1987.

15. Marshall F. The army dental service. Early experience in Egypt [1914-15]. In Butler A G (ed). The Australian army medical services in the war of 1914-1918. Volume III. pp 441. Canberra: Australian War Memorial, 1943.

16. Butler A G. The dental factor. In The Australian army medical services in the war of 1914-1918. Volume I. Part I. pp 361. Melbourne, Australian War Memorial, 1938. 